\title{
Restrictive Licensing of
}

\section{Dental Paraprofessionals*}

In many professions greater use of paraprofessional employees could help to solve problems in the delivery of professional services. By performing jobs formerly handled by professionals, the auxiliary worker frees the professional for more complex tasks and thereby insures a greater total supply of services. In medicine, dentistry, and law, for example, the use of paraprofessionals is increasing, resulting in greater outputs of services by these professions. ${ }^{1}$

The use of paraprofessionals can, however, run afoul of state licensing systems. This Note will examine the licensing restrictions on one group of paraprofessionals-dental auxiliaries-discuss shortcomings in this licensing system, and suggest changes to correct these shortcomings and achieve a system consistent with the proper purposes of licensing.

\section{The Dental Health Problem}

The nation faces an enormous dental health problem. The 24 million United States schoolchildren ages 6-11 average 1.4 decayed, missing, and filled permanent teeth per capita, and 3.0 diseased, nonfunctionalcarious and filled primary teeth per capita. ${ }^{2}$ An even greater frequency of tooth decay is present among adolescents and young children. ${ }^{3} \mathrm{~A}$

* The research for this Note was supported in part by funds from the Robert Wood Johnson Foundation.

1. For example, in 1967 there were 451,500 medical paraprcfessional workers and 137,000 dental paraprofessionals; it is estimated that in 1975 there will be 670,000 medical paraprofessionals and 161,000 dental paraprofessionals. T. GrupenhofF \& S. Strickland, Federal Laws: Health/ENvironment MANPower 82 (1972). Further, an American Medical Association survey shows 21 new formal training programs for physician's assistants (a newly-developed type of medical paraprofessional) graduating their first classes in 1973 and 1974. AMerican Medical Association Department of Health Manpower, 1972 Survey of Operational "Physician's Assistant" Programs: Numbers GRADUATED AND EMPLOYED (1973). For further data on auxiliary personnel in the health fields, see National Center for Health Statistics, Health Resources Statistics, Health Manpower and Health Facilimies 1972-73 (1973). For discussions of the potential use of paraprofessionals to alleviate shortages of health care services, see NATIONAL ADVISORY Comm'N on Health Manpower, Report of the National Advisory Comm'n on Health MANPOWER (1968); Carlson, Health Manpower Licensing and Emerging Institutional Responsibility for the Quality of Care, 35 LAw \& Contemp. Prob. 849 (1970; Forgotson, Bradley \& Ballenger, Health Services for the Poor-The Manpower Problem: Innovation and the Law, 1970 WIs. L. REv. 756 (1970), Forgotson \& Cook, Innovations and Experiments in Uses of Health Manpower-The Effect of Licensure Lau's, 32 Law \& CovTEMr. Prob. 731 (1967); Roemer, Legal Systems Regulating Health Personnel: A Comparative Analysis, 46 MILBANK MEM. FUND Q. 431 (1968).

2. J. Kelly \& J. Scanlon, Decayed Missing and Filled Teeth Among Children 3-17 (DHEW Publications No. HSM 72-1003, Series 11, No. 106, 1971).

3. Id. 
1970 estimate put the number of unfilled cavities in American mouths at 700 million and called the incidence of oral disease "epidemic."4

Severe distributional inequalities in the supply of dental care compound the problem. Low-income urban areas and poorer rural areas tend to have low dentist-population ratios, while middle- and upperclass urban areas have higher ratios. ${ }^{\mathbf{3}}$ Racial and regional differences also exist: Black children have more untreated decayed teeth per capita than white children, and southern children more decayed and fewer filled permanent teeth per child than the national average. ${ }^{6}$

Spurred by the testimony of dental experts, ${ }^{7}$ the federal government has spent heavily in the past 10 years in an attempt to alleviate the dental health problem. Spending has concentrated on subsidizing the training and education of more dentists through construction grants and operating subsidies to dental schools and loan and scholarship programs for dental students. ${ }^{s}$ Although this program has resulted in larger enrollments at United States dental schools, ${ }^{9}$ prices have continued to rise faster than the Consumer Price Index, indicating that the available supply of dental care remains insufficient to meet the rising demand

4. Hearings on H.R. 703 Before the Subcomm. on Public Health and Environment of the House Comm. on Interstate and Foreign Commerce, 92d Cong., 1st Sess. 713 (1970).

5. P. Feldostein, Financing Dental Care: An Economic analysis 57 (1973).

6. J. Kelly \&: J. Scanlon, supra note 2, at 9-10. See also Hearings on H.R. 703, supra note 4 , at 719 . The regional inequalities are illustrated by the fact that, in 1970 , Alabama, Arkansas, Mississippi, North Carolina, and South Carolina each had more than 3,000 persons per dentist, whereas Connecticut, Massachusetts, District of Columbia, New York, Minnesota, California, Oregon, and Washington each had fewer than 1,500 persons per dentist. AMerican Dental Association, Distribution of Dentists in the United States by State, Region, District, and County 4 (1971).

7. See, e.g., Hearings on H.R. 703, supra note 4, at 713; Hearings on S. 3095 Before the Subcomm. on Health of the Senate Comm. on Labor and Public Welfare, 90th Cong., 2d Sess. 46, 205 (1968); Hearings on S. 595 Before the Subcomm. on Health of the Senate Comm. on Labor and Public Welfare, 89th Cong., 1st Sess. 36, 73 (1965); Hearings on S. 911 Before the Subcomm. on Health of the Senate Comm. on Labor and Public IVelfare, 88th Cong., Ist Sess. 171 (1963); Hearings on H.R. 4999 Before House Comm. on Interstate and Foreign Commerce, 87th Cong., 2d Sess. 12, 168, 172, 193 (1962).

8. Between 1965 and 1971 , federal dollars in the following amounts were spent to subsidize dental schools and dental students: construction, \$174,593,472; institutional support, $\$ 88,033,286$; scholarships, $\$ 10,807,822$; student loans, $\$ 37,282,445 ;$ total, $\$ 310$,717,025 . The annual expenditures for each aspect of the program are found in $P$. FELDSTEIN. supra note 5, at 118 . These expenditures were made under the Health Professions Educational Assistance Act, Pub. L. No. 88-129, 77 Stat. 164 (1963), as amended, Pub. L. No. 89-290, 79 Stat. 1052 (1965); and the Health Manpower Act of 1968, Pub. L. No. 90-490, 82 Stat. 773. Further, federal expenditures at substantially the same levels were authorized through fiscal 1974 by the Comprehensive Health Manpower Training Act of 1971, 42 U.S.C. $\$ \$ 292 b-95 g-11$ (Supp. 1, 1971).

This subsidy program has been attacked as too costly compared to alternatives such as the one covered in this Note. See N.Y. Times, Dec. $31,1973, \S 1$, at 15, col. 3 .

9. In 1963, 3,233 new dentists graduated from United States dental schools. P. Feldstein, supra note 5, at 113 . In 1972 , the figure was 3,961 , and 5,337 students were in first-year classes. American Dental association, Annual Report on Dental EDucation 1972/73, at 8, 14 (1973). 
for dental services. Between 1958 and 1971, the Consumer Price Index rose by 44.7 percent, while the "Dentists' fees" price index rose by 68.3 percent. ${ }^{10}$ In this same period the price index for the most basic dental service, "Fillings, adult, amalgam, one surface," rose by 71.1 percent. ${ }^{11}$ These data indicate that the rate of growth of the supply of dental care may still lag behind the rate of growth of demand. Demand will probably continue to increase rapidly in the future if income and educational levels continue to climb or if dental insurance plans are instituted on a large scale. ${ }^{12}$

Federal aid to dental students and schools will help rectify the shortage. However, it is important to consider more efficient means of attacking the problem. One such means, which could be effected at the state level, would be to liberalize the licensing restrictions currently imposed on dental paraprofessional workers.

In order to comprehend the range of possibilities for attacking the dental health problem, and to analyze the potential for increasing the output of dental services, it is useful to view the dentist (or dental office) as a "firm" which produces dental services. ${ }^{13}$ The dentist assumes the role of "manager," combining the various factor inputs into the production of a certain output of dental services. The factor inputs include the dentist's own labor, the labor of his employees, and equipment, such as chairs, drills, and evacuators. Additionally, in his production of dental services, the dentist must work within a framework of technology, which constrains his possible choices of combinations of inputs. "Technology," broadly defined, can be taken to cover the methods known to the dentist, the type of equipment available, and the duties which his employees are legally allowed to perform. ${ }^{14}$

In the long run the total output of dental services can be increased

10. Bureau of Economic Research and Statistics, Expenditures and prices for dental and other health care, 1935 to 1972, 87 JoURNAL OF THE AMERICAN DENTAL Ass'N I442, 1444 (1973) [hereinafter cited as J.A.D.A.]. Further, the noncash elements of the price of dental care have also been rising: the average wait for the first appointment in a series rose from 10.6 days in 1961 to 13.0 days in 1970. AMERICAN DENTAL Assoriation, The 1962 Survey of Dental Practice 52 (1963); Bureau of Economic Research and Statistics, 197I Survey of Dental Practice, IX. Dentist busyness, 85 J.A.D.A. 669 (1972).

11. Bureau of Economic Research and Statistics, Expenditures and prices for dental and other health care, 1935 to 1972 , supra note 10.

12. Demand for dental services is positively correlated to income and years of education, as well as with the amount of insurance coverage. P. FELDSTEIN, supra note 5 , at 51 .

13. The view of the dental office as a firm contrasts with the traditional concept of a self-employed sole practitioner, working with no or perhaps one or two office assistants. A 1971 survey indicated that 73.3 percent of responding dentists were selfemployed without partners. Bureau of Economic Research and Statistics, 1971 Survey of Dental Practice, II. Income of dentists by location, age, and other factors, 84 J.A.D.A. 397,399 (1972).

14. For an interesting empirical measurement of the "production function" in the dental office, see A. Maurizi, Economic Essays on the Dental Profession 57-69 (1967). 
by increasing the number of productive "firms," i.e., by increasing the supply of active practicing dentists with supporting personnel and equipment through subsidization of dental schools. Long-run supply increases can also be brought about by increasing the productivity of the existing "firms." In the short run, however, increases in dental services can only come from increased productivity by the individual "firms."

There are several sources of productivity from within the firm. First, the dentist himself may work longer hours, that is, increase his own time input. However, for a dentist already working a full week of 40 hours or more, the potential for increased output from increased hours is obviously relatively small. ${ }^{15}$

Second, increased firm productivity may come from technological improvements, such as development and use of more efficient methods and equipment. The annual increase in dental productivity due to technical change has been estimated to be no greater than 1.5 percent. ${ }^{16}$

Finally, increased productivity may come from greater utilization of auxiliary personnel. Such increased utilization might take two forms: (1) hiring of more auxiliaries to do "traditional" auxiliary functions, or (2) delegating tasks traditionally performed by dentists to auxiliaries. Many studies have been conducted on the effects on quality and output of services of this second approach. ${ }^{17}$ These studies have uniformly

15. In 1970, the average dentist's workweek was 41.4 hours. Bureau of Economic Research and Statistics, 1971 Survey of Dental Practice, VII. The dentist's workweek and workyear, 84 J.A.D.A. 1385 (1972). Further, average annual dentist hours worked have diminished slightly over time. The 1961 average dentist hours worked per year was 2037.3; the 1970 figure was 1949.9. American Dental Association, the 1962 Survey of Dental Practice 39, 40 (1963); 84 J.A.D.A. at 1386-87.

16. A. Maurizi, supra note 14, at 68-69 (1967); American Council on Education, Commission on the Survey of Dentistry in the United States, The Survey of DENTISTRY 478 (1961).

17. By "studies" is meant controlled experiments simulating conditions in a dental office or clinic, but using "expanded function auxiliaries" (EFA's) in addition to or in place of the usual paraprofessionals. In each of these experiments the EFA was allowed to perform slightly different functions, but in all of them the auxiliary did a substantial number of tasks usually permitted to be performed only by dentists.

For documentation of some of the major domestic studies, see W. Ludwig, E. Schoebelen \& R. Knoedler, Greater Utilization of Dental Technicians, I. Report of Training (1963); II. Report of Clinical Tests (1964) (U.S. Naval Training Station, Great Lakes, IIl.); Abramowitz, Expanded functions for dental assistants: a preliminary study, 72 J.A.D.A. 386 (1966); Abramowitz \& Berg, A four-year study of the utilization of dental assistants with expanded functions, 87 J.A.D.A. 623 (1973); Hammons, Jamison \& Wilson, Ouality of service provided by dental therapists in an experimental program at the University of Alabama, 82 J.A.D.A. 1060 (1971); Hammons \& Jamison, Expanded functions for dental auxiliaries, 75 J.A.D.A. 658 (1967); Hammons \& Jamison, Increasing the productivity of dental auxiliaries, 35 AMrerican COLlege Dentists J. 154 (1968); Lotzkar, Johnson \& Thompson, Experimental program in expanded functions for dental assistants: phase 3 experiments with dental teams, 82 J.A.D.A. 1067 (1971); Pelton, Overstreet, Embry \& Dilworth, Economic implications of adding one therapist to a practice, 86 J.A.D.A. 1301 (1973); Pelton, Bethart \& Goller, The ability of dental therapists to perform oral prophylaxis, 84 J.A.D.A. 611 (1972); Soricelli, Practical Ex- 
concluded that the dental "firm" could greatly increase its output of services through delegation to auxiliaries of tasks traditionally performed by the dentist. ${ }^{18}$ Further, the studies show that auxiliaries can be trained to perform these tasks on as high a level of quality as the dentist. ${ }^{19}$ This training can be completed in a relatively short time, compared to the time necessary to educate a dentist. ${ }^{20}$ The dentist is

perience in Peer Review Controlling Quality in the Delivery of Dental Care, 61 AM. J. Pub. Health 2046 (1971).

For documentation of major foreign programs in which EFA's are used in actual practice, see Baird, Shillington \& Protheroe, Pilot Study on the advanced training and development of auxiliary dental personnel in the Royal Canadian Dental Corps, 28 Can. DENT. Ass'N J. 627 (1962); Berman, Utilization of the Dental Auxiliary-School Dental Nurse, 19 INT'L DENT. J. 24 (1969); Leatherman, Survey of Auxiliary Dental Personnel, 19 INT'L DENT. J. 49 (1969); Walsh, The Dental Nurse, 32 AM. College DENTISTS J. 62 (1965).

For further discussion, see Worlo Health Organization, Report of the Expert Conmittee on Dental Auxiliary Personnel (Technical Report Series No. 163, 1969); Ast, Changes in Oral Health Delizery Systems Resulting From Implementation of More Efficient Preventative Measures and Greater Delegation of Responsibilities to Ausiliaries, in Position Papers on AN Improved Oral Care System (W. Brown cd. forthcoming); Arnold, The Dental Assistant, The Clinical Chairside Assistant, and The Dental Hy. gienist as Members of the Dental Team in General Practice, 19 INT'L DENT. J. 12 (1969).

18. The following data are illustrative of the productivity measures achieved in the experiments cited in note 17 supra. In the Lotzkar, Johnson and Thompson study, a team of one dentist and three EFA's treated 62 percent more patients, performed 84 percent more procedures, and accomplished 80 percent more time units of work than a control team of one dentist, one chairside assistant, and several office helpers. A team of one dentist and four EFA's was 133 percent more productive than the control team, using the "procedures completed per day" measure of output. Lotzkar, Johnson 8: Thompson, supra note 17, at 1067. In the study reported by Soricelli, a team of one dentist, three EFA's, two "traditional" assistants, and one office clerk was found to be capable of doing as much work as four dentists working with one "traditional" chairside assistant. Soricelli, supra note 17 , at 2046 . In the study reported by Baird, Shillington and Protheroe, the addition of one EFA to a control team of one dentist and two assistants increased "firm" productivity by 99.1 percent. Other teams, consisting of one dentist and one EFA, accomplished on the average in a 6.5 hour workday the same amount of work done by a solo dentist in 10.5 hours-a 61.5 percent increase. Baird, Shillington \& Protheroe, supra note 17, at 627.

19. In the studies cited in note 17 supra, quality of care provided by EFA's was usually measured by having impartial dentists compare the completed work on patients treated with EFA's with the completed work on patients treated by dentists; the patients were also questioned as to their general satisfaction with the quality of treatment received. For example, in the Abramowitz study, the quality of the EFA's work was found to not differ significantly from that of a dentist. Abramowitz, supra note 17, at 386. In the Lotzkar, Johnson and Thompson study, the independent dentists pronounced the work performed by the EFA's to be highly satisfactory from a professional viewpoint, and the patients indicated a high degree of satisfaction with the work provided. Lotzkar, Johnson \& Thompson, supra note 17, at 1067.

20. Two to four years of pre-professional education and four years of professional education are required to train a dentist. Further, the cost of education of a dental student, for the four years of professional training, has been estimated at $\$ 30,000$. P. Feldstein, supra note 5, at 96 . By comparison, training a "traditional" dental hygienist takes only two years beyond high school. The reports cited in note 17 supra indicate that the EFA's used in the experiments required the additional training to perform expanded functions as follows: EFA's receiving approximately threc to ten months training: Taking impressions for study casts; Placing and removing rubber dams; Placing and removing matrix bands (also selection and contour); Condensing and carving amalgam restorations in previously prepared teeth; Placing silicate and acrylic restorations in previously prepared teeth; Applying final finish and polish to restorations; Placing and removing temporary restorations; Inserting cavity liners and bases; Selecting tooth 
thus freed for other, more complicated tasks which require his professional skill and judgment, and the total amount of services produced per dentist is increased with no reduction in quality of care. In several foreign countries (e.g., New Zealand, Australia, and Malaysia), such "expanded function auxiliaries" (EFA's) have been used on a large scale in the provision of dental services; the experiences in these countries support the finding that the use of EFA's results in the production of more services per dentist without any quality reduction. ${ }^{21}$

Against this background, then, one can see that the dentist is not the only input, albeit the most important, into the production of dental care, and that quicker and cheaper increases in output would be realized through greater use of other inputs, specifically, through delegation of expanded functions to paraprofessional employees. The operation of this market mechanism, however, is severely hampered by an artificial imperfection: the licensing system which restricts auxiliaries' permissible functions.

\section{Licensing of Dental Auxiliaries}

A licensing system is a restraint on competition imposed by the state in hopes of achieving certain benefits. These benefits include admission to practice of only those candidates who demonstrate a certain level of competence, maintenance of a high quality of service (in accord with modern technological progress), protection of consumers from fraud and dishonesty, and provision of information to consumers who might otherwise be disadvantaged because of lack of knowledge of the competency of professionals. ${ }^{22}$

A licensing system, however, by defining the limits of particular professions and trades to include only certain existing practices and to exclude others, may inhibit the development and use of new techniques and skills. ${ }^{23}$ Moreover, vesting control of the licensing authority in representatives of the professional group may subordinate the general consideration of the public interest to consideration of monopo-

shade; Placing and removing periodontal packs; Taking $x$-rays, roentgenograms, etc. EFA's receiving additional training, up to a total of two years, performed the above plus the following additional tasks: Extractions under local anesthesia; complete restorations in primary and permanent teeth (using copper amalgam, silver amalgam, and silicates): and treatment planning.

21. See, e.g., Berman, supra note 17; Leatherman, supra note 17; Walsh, supra note 17.

22. See Council of State Governments, Occupational Licensing in the States 3 (1952); M. FRiedman, CapitalisM and Freedom 147 (1962).

23. Council of State Governarents, supra note 22, at 4. 
listic group advantage. ${ }^{24}$ The current system of legal restrictions on dental auxiliaries has led to both of these abuses.

All 50 states prescribe some manner of licensing of dental auxiliaries. ${ }^{25}$ In a dwindling minority of states the licensing statute defines explicitly the functions legally permitted to dental hygienists; hygienists may perform no duties other than those enumerated. ${ }^{26}$ These

24. W. Gellhorn, Individual Freedom and Government Restraints 140 (1956). See also Holen, Effects of Professional Licensing Arrangements on Interstate Labor Mobility and Resource Allocation, 73 J. Polrr. EcoN. 492, 494, 496, 498 (1965); Moore, The Purpose of Licensing, 4 J. LAw \& EcoN. 93, 98, 117 (1961); Stigler, The theory of economic regulation, 2 BELL J. ECON. \& MGMT. SCIENCE 3 (1971).

25. For reference, the pertinent statutes of each state are listed below:

Ala. Code tit. 46, $\S \S 120(1)$ et seq. (Supp. 1971); AlASKa STat. $\S \S 08.32 .010$ et seq., $\$ \$ 08.36 .10$ et seq. (1962); ARIz. REv. STAT. ANN. $\$ \$ 32-1201$ et seq. (Supp. 1973); ARK. Stat. Ann. $\S \S 72-501$ et seq. (Supp. 1969); Caz. Bus. \& Prof. Code $\$ \S 1600$ et seq. (West Supp. 1973); Colo. Rev. Stat. AN. \$\$ 42-1-1 et seq. (1963); Conn. Gen. Stat. ANN. $\$ \S 20-103$ et seq. (Supp. 1971); DEL. CODE ANN. tit. 24, \$\$ 1101 et seq. (Supp. 1970); FLA. Stat. ANn. $\$ \$ 466.01$ et seq. (1965); GA. Code ANN. $\$ \$ 84-701$ et seq. (Supp. 1973); Hawail Rev. STAT. $\S \S 447-1$ et seq., $\$ \S 448-1$ et seq. (Supp. 1972); IDAHo Code $\$ \S 54-901$ et seq. (Supp. 1973); ILl. REv. STAT. ch. 91, $\$ \$ 56 \mathrm{a}$ et seq. (Smith-Hurd Supp. 1973); IND. ANN. STaT. \$\$ 63-501 et seq. (Supp. 1973); Iowa CodE ANN. \$\$ 147.1 et seq., $\$ \$ 153.1$ et seq. (Supp. 1973); KAN. STAT. ANN. \$\$65-1401 et seq., \$\$ 74-1404 et seq. (1972); Ky. Rev. Stat. $\$ \$ 313.010$ et seq. (1971); LA. Rev. STat. $\$ \$ 37-751$ et seq. (Supp. 1974); ME. Rev. Stat. ANN. tit. 32, \$§ 1071 et seq. (Supp. 1973); MD. ANN. Code art. 32, $\S \S 1$ et seq. (Supp. 1973); Mass. ANN. Laws ch. 112, $\$ \$ 43$ et seq. (Supp. 1972); Mich. Comp. Laws ANn. \$§ 338.201 et seq. (1967); Minn. Stat. ANN. \$\$ I50A.01 et seq. (Supp. 1970); Miss. ConE ANN. $\$ \$ 73-9-1$ et seq. (1972); Mo. ANN. STat. \$\$ 332.010 et seq. (Supp. 1974); Mont. Rev. Codes AnN. $\$ \S 66-901$ et seq. (Supp. 1969); Neb. Rev. Stat. $\$ \$ 71-101$ to -172 , $\$ \$ 71-183$ to -193.14 (1971); NEv. REv. STAT. $\$ \$ 631.010$ et seq. (1963); N.H. Rfv. Stat. ANN. \$ 317-A:1 (Supp. 1972); N.J. STAT. ANN. \$\$ 45:1-2.1 to 45:1-7, 45:6-1 to 45:6-47 (Supp. 1973); N.M. StAT. ANN. \$\$ 67-4-1 et seq. (Supp. 1973); N.Y. Educ. LAw $\$ \S 6500-15, \$ \S 6600-11$ (McKinney Supp. 1973); N.C. GEN. STAT. $\$ \$ 90-22$ to -48.1, $\$ \$ 90-221$ to -233.1 (Supp. 1973); N.D. CENT. CODE $\$ \$ 43-20-01$ et seq., $\$ \$ 43-28-01$ et seq. (Supp. 1973); OHIO Rev. Code ANN. $\$ \$ 4715.01$ et seq. (Page Supp. 1972); OkLA. Stat. tit. 59, $\$ \$ 328.1$ et seq. (Supp. 1973); ORE. Rev. STAT. $\$ \$ 670.010$ et seq., $\$ \$ 679.010$ et seq., \$\$ 680.010 et seq. (1971); PA. STAT. ANN. tit. 63, \$\$ 120-306 (Supp. 1972); R.I. GEN. LAWS ANN. $\S \S 5-31-1$ et seq. (Supp. 1972); S.C. CoDE ANN. $\$ \S 56-636.1$ to -.38 (Supp. 1972); S.D. CoMp. LAws ANN. \$§ 36-6-1 et seq. (1967); TENN. CODE ANN. \$\$ 63-530 to -560 (Supp. 1973); Tex. Rev. Civ. STAt. ANN. arts. 4543-51g (1973); UTAH Code ANN. $\$ \S 58-1-1$ et seq., $\$ \$$ 58-7-1 et seq., $\$ \S 58-8-1$ et seq. (Supp. 1973); VT. STAT. ANN. tit. $26, \S \S 721-865$ (1973); VA. CODE ANN. $\$ \S 54-146$ to -200.02 , $\$ \S 54-200.1$ to -.22 , $\$ \S 54.1$ to -1.2 (Supp. 1973); WASH. Rev. CoDE ANN. $\$ \S 18.29 .010$ et seq., $\$ \S 18.32 .010$ et seq. (Supp. 1972); W. VA. Code ANn. $\$ \$ 30-4-1$ et seq. (Supp. 1973); WIs. STat. ANN. $\$ \$ 447.01$ et seq. (1970); WYo. Stat. ANN. \$§ 32-192.1 et seq. (Supp. 1973).

26. A typical statutory definition of the functions of the hygienist is as follows: Such licensed hygienists may remove calcareous deposits, accretions, and stains from the teeth, and may prescribe or apply ordinary mouthwashes of soothing character, but shall not perform any other operation on the teeth, mouth, or tissues of the oral cavity, or administer any therapeutic remedies to diseased portions of teeth or their surrounding tissues.

Mich. Comp. Laws AnN. \$ 338.209 (1967). See also ARIz. Rev. Stat. AnN. \$ 32-1281 (1956); Cal. Bus. \& Prof: Code $\$ 1746$ (West 1962); Mass. AnN. Laws ch. 112, $\$ 51$ (1965); N.J. Stat. ANN. \$ 45:6-33 (1963); R.I. GEN. LAWS ANN. \$ 5-31-13 (1956); Ùtari CODE ANN. $\$ 58-8-9$ (1953). These seven states are all that remain of the 27 states whose statutes in 1971 specifically enumerated the functions a hygienist could perform. Division of Dental Health, Bureau of Health Resources Development, Health Resources Admin., Public Health Service, Dep't of HEW, Tabular Summaries of Legal Provisions Among the States on Expanded Functions for Dental Auxiliaries, Sept. 1973 [hereinafter cited as Division of Dental Health]. Further, the California legislature has called for a report on the status of dental auxiliary education and "career progression," 
statutes generally ignore dental assistants; ${ }^{27}$ however, they may contain an implicit definition of the assistant's functions, in that they define the functions which constitute the "practice of dentistry" and then prohibit persons lacking a dentist's license from performing these functions. ${ }^{28}$ Under these statutes the dental assistant's role is limited to that of an office helper. The assistant's tasks have typically included receiving patients, scheduling appointments, answering telephones, billing and bookkeeping, cleaning equipment and instruments, seating the patient, and aiding the dentist as he works by handing him instruments, rinsing the patient's mouth, and performing other such minor tasks. ${ }^{29}$ Rather than receiving any formal education as most hygienists do, these assistants have traditionally been trained "on the job" by the dentist himself. Despite an increase in formal training programs for assistants, the majority employed today were probably trained on the job. ${ }^{30}$

During the past six years many states have abandoned the "explicit definition" form of statute in favor of more flexible statutory schemes. The newer statutes generally have three common features: (I) an "open" provision, allowing the dentist to delegate to his auxiliaries any tasks not requiring the dentist's "professional judgment and skill," provided that such delegated tasks are performed under the dentist's supervision; ${ }^{31}$ (2) a delegation of rulemaking authority to the dental board to determine more precisely what tasks the dentist may allow his auxiliaries to perform; ${ }^{32}$ and (3) a listing of tasks prohibited to the

possibly with the intention of liberalizing auxiliary functions, see Car. Bus. \& Prof. CODE $\$ \$ 1820-25$ (West Supp. 1973), and a new statute is pending in Michigan. See House Bill No. 4114 , Feb. $13,1973$.

27. The Michigan, New Jersey, Rhode Island, Ohio, and Utah statutes, for example, make no mention of dental assistants. Mich. CoMp. LAws ANN. $\S \S 338.201$ et seq. (I967); N.J. STAt. ANN. \$§ 45:6-I to -47 (1963); OHIo Rev. CODE ANN. $\$ \$ 4715.01$ et seq. (Page 1953); R.I. Gen. LAwS ANn. \$\$ 5-31-1 et seq. (1956); UTAH CODE ANN. \$\$ 58-7-2 et seq., $\$ \$ 58-8-1$ et seq. (1953), \$ 58-7-11 (Supp. 1973)

28. See, e.g., N.J. Stat. ANN. $\$ \$ 45: 6-19$, 45:6-13 (1963). The first section lists the functions which constitute the practice of dentistry; the second lists penalties for practicing dentistry "within the meaning of this chapter" without a license.

The Massachusetts statute prohibits dentists from allowing their assistants to perform substantial "clinical" work, as follows: "[A]ny registered dentist or incorporated dental company who employs or permits a person to practice dentistry unless such person is registered . . as provided in sections forty-four and forty-five [dealing with examination and registration of dentists $]^{\prime \prime}$ shall be subject to various listed penalties. MAss. ANN. LAws ch. 112, $\$ 52$ (1965) (ch. 112, \$ 50 defines "practicing dentistry").

29. M. Cussier \& E. Gordon, Dentists, Patients and Auxiliaries 56 (I968); W. Young

\& D. Striffler, The Dentist, His Practice, and Hrs Community $281-82$ (1969).

30. W. Young \& D. STRIFfLER, supra note 29, at 281.

31. See, e.g., Colo. Rev. Stat. ANn. \$ 42-1-28(3) (Supp. 1971); Ind. ANn. Stat. \$ 63-522 (Supp. 1973); Mo. ANn. Stat. \$ 332.091 (Supp. 1974); Oho Rev. Code ANN. \$ 4715.23 (Page Supp. 1972); TENN. CODE ANN. \$ 63-537(c) (Supp. 1973).

32. See, e.g., Hawail Rev. Stat. \$ 447-3 (Supp. 1972); Ky. Rev. Stat. \$\$ $313.010(3)$, 313.220(4) (1971); Mo. ANN. Stat. $\$ \$ 332.031$, 332.091 (Supp. 1972); Ohio Rev. Code ANN. $\$ 4715.23$ (Page Supp. 1972); Tex. Rev. Crv. Srar. ANN. arts. 4551d-e (Supp. 1974); VA. CoDE ANN. $\S \S 54-200.2,54-200.4$ (Supp. 1973). 
auxiliaries, and/or a further delegation of authority to the state board to determine what functions shall be prohibited..$^{33}$ Despite their broad rulemaking authority, however, the majority of dental boards have not permitted substantially more responsibility to auxiliaries than was allowed under the older, "special-listing" statutes. ${ }^{34}$ As a result, a wide range of expanded functions, which can be safely and efficiently performed by properly-trained auxiliaries, remains legally off-limits to these paraprofessionals. ${ }^{35}$

33. Idaho, for example, grants the state dental board authority to specify what functions dental hygienists and assistants may perform, but specifically prohibits hygienists from carrying out surgical procedures on tissues, diagnosis and treatment planning, taking impressions from which appliances will be made, and writing prescriptions. IDAHO CODE $\$ S 54-902$, 54-912(a) (Supp. 1973). Further, hygienists may practice only when under the supervision of a licensed dentist. Id. $\$ 54.904$ (Supp. 1973). The state board in 1972 issued regulations allowing hygienists the following duties: polishing of fillings, removing sutures and periodontal packs, and administering local anesthesia under the dentist's supervision. These regulations allow the dental assistant to as: sist with the placement of rubber dams, to place matrix bands, and to do other nontraditional tasks, but prohibit them from making oral impressions, placing or carving any restorations, placing or removing sutures or periodontal packs, adjusting oral ap* pliances, administering anesthesia, and polishing teeth. D. Johnson \& F. Holz, Legal Pro. visions on Expanded Functions for Dental Hygienists and Assistants, Summarized by State, 1973 , at $40-42$.

34. Most states prohibit auxiliaries either through express exclusion or via omission from:

Diagnosis and establishment of treatment plans; Cutting of or surgery on hard or soft tissues; Participation in fabrication of any appliance to be worn orally, which could come in contact with hard or soft tissue and cause irritation; Injec-

tions of anesthetics; Prescription of drugs; Placing of permanent restorations;

Taking of oral impressions for anything but study casts.

See D. Johnson \& F. Holz, supra note 33 , and the state statutes cited supra note 25 . Statutes that serially list functions prohibited to the dental auxiliary include N.D. Cent. Cone Ann. \$ 43-20-12 (Supp. 1973); Ohro Rev. Code Ann. \$ 4715.23 (Page Supp. 1972); S C. Code ANN. $\$ 56636.11$ (Supp. 1972); TENN. Code ANN. $\$$ 63-537(c) (Supp. 1973); Wash. Rev. CodE ANN. $\$ \S$ 18.29.050, 18.32.030(11) (Supp. 1972). Statutes that serialiy list functions permitted to the dental auxiliary include the statutes cited supra notes 26.27, plus N.C. Gen. STAT. \$ 90-221(a) (Supp. 1973); TenN. Code ANN. $\$$ 63-537(b) (Supp. 1973); Tex. Rev. Civ. Srat. ANn. art. 455le (Supp. 1973).

In addition to explicit listings, general statutory and regulatory language, such as that "prohibiting auxiliaries from performing procedures "requiring the dentist's professional judgment and skill," or requiring direct supervision by the dentist when the auxiliary performs certain tasks, can also effectively bar the delegation of expanded functions. See, e.g., Colo. Rev. Stat. ANN. $\$ 42-1-8(3)$ (Supp. 1972); INd. ANN. STAT. $\$ 63-522$ (Supp. 1973); Miss. Code ANn. \$ 73-9-5 (1972); N.D. CENT. Code ANN. \$ 43-20-12 (Supp. 1973); Ohio Rev. Code Ann. \$ 4715.22 (Page 1953); Tenn. Code ANn. \$63-537(c) (Supp. 1973). Of the 32 states with some operative provision for allowing expansion of auxiliary responsibilities through dental board regulations, none perm:ts an auxiliary to engage in diagnosis and treatment planning, tasks which a properly-trained auxiliary can perform safely and effectively. D. Johnson \& F. Holz, supra note 33. Only seven of these states permit any auxiliary to place, carve, and finish an amalgam restoration, and only eight allow auxiliaries to place, carve, and finish silicate restorations. Only nine of these 32 states permit an auxiliary to administer a local anesthetic. Division of Dental Health, supra note 26. The remaining 18 states prohibit all expanded functions, either through explicit statutory definitions of functions (see notes 26.27 supra), or due to the failure of the state dental board to allow expanded functions pursuant to its statutory authorization. Division of Dental Health, supra note 26.

35. Of the expanded functions performed in the various experiments and foreign programs, see note 17 supra, and listed in note 20 supra, the following appear to remain generally prohibited: placing, carving, and finishing restorations; examinations; treatment planning; extractions; and the operative procedures of restorations. See 
There are two explanations for the failure of dental boards to allow the performance of broad expanded functions by auxiliaries, despite the boards' statutory power to do so. One is a resistance to innovation built into the board by the statutes establishing them. Many state statutes have provisions assuring that the board will be composed of older, more experienced dentists. These provisions may take the form of requiring a minimum amount of time in practice before one is eligible to be on the board, ${ }^{36}$ or requiring that board members be selected only from nominees of the state dental association. ${ }^{37}$ The dental society's nominees would most likely be older practitioners who have put in years of service to the dental society.

The hypothesis that appointment of older dentists to state licensing boards will cause the boards to take an unfavorable attitude toward allowing expanded functions for auxiliaries has empirical support. Younger practitioners are more receptive to the utilization of auxiliaries than older dentists, and younger dentists are more likely to delegate tasks to auxiliaries, if permitted, than are older dentists. ${ }^{38}$

Another common statutory provision resulting in licensing board inertia is the requirement that no board member be affiliated with a

Division of Dental Health, supra notes 26 \& 34; D. Johnson \& F. Holz, supra note 33. Further, to the extent that auxiliaries are permitted some expanded duties, the potential productivity increases from delegating these procedures are limited by the legal requirement that the auxiliary work under the "direct supervision" of the dentist. Statutory language holding the dentist fully responsible for any work done by the auxiliary may also have an inhibiting effect on dentists stich that they refrain from delegating expanded functions to their auxiliaries. See, e.g., IND. ANN. STAT. \$§ 63-522, 63.537(c) (Supp. 1973).

36. Many statutes set the required time in practice at five or 10 years, and some further qualify this by specifying that the years of practice have been continuous in the licensing state. See, e.g., Conn. Gen. Stat. Ann. $\$ 20-104$ (1958); Pa. Stat. Ann. tit. $71, \$ 124$ (1962).

37. The Pennsylvania statute, for example, provides:

The Pennsyliania State Dental Society shall have power to nominate, from its membership, at least double the number of candidates required to fill the va. cancies occurring annually in the membership of the State Dental Council and Examining Board ... . The Governor shall appoint members to fill all vacancies, occurring from any cause, only from the candidates nominated as aforesaid.

Pa. Stat. Ann. tit. 71, § 124 (1962). See also Ind. Rev. Stat. ch. 91, § 58a (Smith-Hurd Supp. 1973); OHro REv. Code ANn. \$ 4715.02 (Page 1954).

38. Brown, Increasing productivity and reducing disease: The dental health team: potential role of auxiliaries, 75 J.A.D.A. 882 (1967); Council on Dental Education, Review and Discussion of Opinion Survey on Educational Standards in Dental Assisting, 76 J.A.D.A. 1056-63 (1968).

Indeed, one might argue that, since new and innovative techniques and task assignments are most likely to be introduced first in dental school clinics and research projects, one who has been away from dental school for a long time is in the worst position to rule on legalizing these innovations. This would certainly apply to a dentist who received his degree many years ago and has since been in practice using essentially the same methods that he was taught in school. This effect may be mitigated in those few states which statutorily require "continuing education" by the dentist as a condition to license renewal. See, e.g., MINN. STAT. ANN. \$ 150A.09(2) (1970); N.D. CENr. CODE $\$ 43-28-12.2$ (Supp. 1973). 
dental school. ${ }^{39}$ The dental professor, through his association with the dental school, has probably had greater exposure to new methods, techniques, and task assignments, including expanded functions for auxiliaries. $\mathrm{He}$ is, hence, in a better position to judge the safety and efficacy of innovations than is a dentist who has been in practice for a period of time.

The second explanation for the failure of most state licensing boards to authorize broad expanded duties for auxiliaries lies in the economic self-interests of the board members (and of dentists in general). As auxiliaries are allowed to perform higher levels of expanded functions, they become substitutes for dentists in the dental care "production function." They therefore begin to compete with dentists, at least to the extent that a dentist, making efficient use of several EFA's, might be able to provide services to a clientele formerly served by several solo dentists. Dental board members, who are generally well-established practitioners and well-established dental society members, threatened by possible competition from dental auxiliaries, may utilize their positions of power on the board to exclude auxiliaries from the dental market by promulgating restrictive auxiliary regulations. ${ }^{40}$

Whether the use of expanded function auxiliaries would ever drive a solo practitioner out of business is not the crucial point. Allowing auxiliaries to perform expanded functions would result in an increase in the amount of services supplied by the individual dental office, and hence by the dental services industry as a whole. The use of EFA's might therefore result in lower prices for dental care than otherwise. Paraprofessional licensing restrictions may thus also be imposed as a

39. Utah's provision in this regard is typical: "[N]o member of such licensing committee shall be a member of the faculty of any dental college or dental department of any medical college." UTAH CoDE ANN. $\$ 58-1-5(6)$ (1953). See also ILL. REv. STAT. ch. 91, \$ 58a (Smith-Hurd Stpp. 1973); PA. Srat. ANN. tit. 71, § 124 (1962). The Texas statute is even more comprehensive, prohibiting from board membership "members of the faculty of any dental or dental hygiene school or college or of the dental or dental hygiene department of any medical school or college." TEX. REv. Civ. STAT. ANN. $\$ 4543$ (Supp. 1973). The recently-amended California dental practice act now allows "no more than one member of the board" to "be a member of the faculty of any dental college or dental department of any medical college in the state of California." GAL. Bus. \& Prof. CODE \& 1602 (West Supp. 1973).

40. The situation is somewhat analogous to that occurring at times in medicine (or other areas of "self-regulation") when a "group practice," which makes efficient use of paramedical technicians and economies of scale to produce lower cost services, enters an area formerly served by numerous solo practitioners. In this situation the solo practitioners have sometimes, through their local medical society, used their monopoly position (with respect to control over access to hospital facilities) and other restrictivc practices to try to drive the intruders out of business. See, e.g., American Medical Ass'n v. United States, 130 F.2d 233 (D.C. Cir. 1942), aff'd, 317 U.S. 519 (1943); Willis v. Santa Ana Community Hospital Ass'n, 58 Cal. 2d 806, 376 P.2d 568, 26 Cal. Rptr. 640 (1962); Tatkin v. Superior Court, 160 Cal. App. 2d 745, 326 P.2d 201 (1958); Group Health Cooperative v. King County Medical Society, 39 Wash. 2d 586, 237 P.2d 737 (1951). 
means of restricting supply, hence maintaining high prices and profits for dentists. ${ }^{41}$

Thus these potential productivity increases of the dental "firm," available, without decreasing the quality of dental care, through use of expanded function auxiliaries, are frustrated by the system of legal restrictions. The possibilities for using the EFA "input" to provide a quick yet safe amelioration of current dental care problems are thus severely limited; and government attention remains focused on the much more expensive and time-consuming alternative of subsidizing increased production of dentists. The public bears the costs by having public funds diverted for this purpose, by a lesser availability of dental care, and by higher prices for the services that are available. ${ }^{42}$

\section{Changing the Auxiliary Licensing System}

Two possible bases exist for judicial attack by dental paraprofessionals on the licensing system: due process (under the Fourteenth

41. Ordinarily the enforcement problems in an industry having as many small firms as dentistry would make cartelization impossible. G. STIGLER, THE THEORY of Price 273 (1947). Cartels are inherently unstable because of the profitability to the individual firm of violating the agreement. Thus enforcement of the agreement among firms to set prices or restrict output is the major problem facing a cartel. D. BODENhorN, Intermediate Price Theory 241 (1961); G. Stigler, supra at 238-39; D. WAtson, Price Theory AND ITs USEs $372-73$ (2d ed. 1968). In the case of dentistry, restriction of output is accomplished through an agreement not to use a highly-productive input, the expanded function auxiliary. See, e.g., Resolution 78-1972-H that "development of new categories of dental auxiliaries is not accepted by the American Dental Association and that only the dental assistant, dental hygienist, and dental laboratory technician are recognized as dental auxiliaries." American Dental Association, 1972 Transactions 707.07 (1973). Dentists, through their control of paraprofessional licensing, are able to give the agreement the force of law. If the licensing laws were amended to permit paraprofessionals to perform broad expanded functions, dentists still might agree among themselves not to hire EFA's. However, the absence of state enforcement of the agreement would result in disintegration of the cartel due to the profitability of violating the agreements.

42. The value of the reduced amount of output caused by higher prices is the "dead-weight loss" (or "welfare loss") to society of monopoly. See P. SAmuerson, ECoNomics 492 n.10 (7th ed. 1967); D. WaTson, supra note 41, at 317. Milton Friedman has commented on this welfare loss of licensing monopolies as follows:

Trained [dentists] devote a considerable part of their time to things that might well be done by others. The result is to reduce drastically the amount of [dental] care. The relevant average quality of care, if one can at all conceive of the concept, cannot be obtained by simply averaging the quality of care that is given; that would be like judging the effectiveness of a medical treatment by considering only the survivors; one must allow also for the fact that the restrictions reduce the amount of care. The result may well be that the average level of competence in a meaningful sense has been reduced by the restrictions.

M. Friedian, supra note 22, at 156.

Besides the losses to the public, the licensing system denies dental paraprofessionals themselves the opportunity to perform expanded functions (even though individual paraprofessionals may be perfectly competent to do so). The effect of the system of legal restrictions is that beyond a certain group of tasks, no matter how competent he proves himself, the candidate will not be allowed to practice further skills. This deprives the auxiliary of the opportunity to use to his pecuniary advantage the training and ability he may have acquired. 
Amendment) and antitrust. Neither contemporary due process doctrine nor the antitrust laws, however, provide a promising means of modifying the licensing system.

Due process imposes requirements of specificity, ${ }^{43}$ rationality, ${ }^{44}$ and procedural fairness ${ }^{45}$ on state action. With respect to the auxiliary licensing system, specificity goes to the standards and guidelines used in the statute or by the dental board; rationality requires a reasonable relation between the standards imposed and the purpose to be achieved (e.g., high-quality dental care); and procedural fairness goes to the composition of the board and its procedures. ${ }^{46}$

Substantial empirical evidence exists that current auxiliary restrictions are not justifiable in light of the recognized purposes of licensing. ${ }^{47}$ This might suggest that licensing restrictions constitute an arbitrary interference with an auxiliary's right to pursue his chosen profession, ${ }^{48}$ a right implicit in the concept of "ordered liberty." However, it is more likely that a reviewing court would view a licensing restriction as a permissible exercise of state regulation of health and safety rather than as an interference with a constitutionally-protected right. Courts no longer require that legislation bear a "real and substantial relation to the public health, safety, morals, or some other phase of the general welfare." These are considerations for the legislative choice, and courts are generally reluctant to substitute their own judgments

43. Interstate Circuit, Inc. v. Gity of Dallas, 390 U.S. 676 (1968); Hornsby v. Allen, 326 F.2d 605 (5th Gir. 1964).

44. Williamson v. Lee Optical Co., 348 U.S. 483 (1955); Nebbia v. New York, 291 U.S. 502 (1934); Lochner v. New York, 198 U.S. 45 (1905); Dent v. West Virginia, 129 U.S. 114 (1889).

45. Gibson v. Berryhill, 411 U.S. 564 (1973); Western Union Tel. Co. v. Pennsylvania, 368 U.S. 71 (1961); In re Murchison, 349 U.S. 133 (1955); Tumey v. Ohio, 273 U.S. 510 (1927).

46. See Note, Due Process Limitations on Occupational Licensing, 59 VA. L. REv. 1097, 1103 (1973).

47. See pp. 809-11 \& notes 17-21 supra.

48. The right to pursue one's chosen profession is one which may not be deprived without due process of law: it includes "the right of the citizen to be free in the enjoyment of all his faculties; to be free to use them in all lawful ways; to live and work where he will; to earn his livelihood by any lawful calling." Allgeyer v. Louisiana, 165 U.S. 578, 589 (1897). See also the dissent of Justice Douglas in Barsky v. Board of Regents, 347 U.S. 442 , 472 (1954), stating that the right to work is the "most precious liberty man possesses"; New State Ice Co. v. Liebmann, 285 U.S. 262, 278 (1932); Truax: v. Raich, 239 U.S. 33, 41 (1915); Coppage v. Kansas, 236 U.S. 1, 14 (1915). More recent Supreme Court decisions have established that the practice of a chosen occupation is a right rather than a mere privilege. Keyishian v. Board of Regents, 385 U.S. 589 (1967); Cramp v. Board of Public Instruction, 368 U.S. 278 (1961); Greene v. McElroy, 360 U.S. 474 (1959); Schware v. Board of Bar Examiners, 353 U.S. 232 (1957).

However, Allgeyer, Coppage, Truax, and Liebmann were dec.ded under an "economic due process" rationale that has been largely abandoned by the Supreme Court. No. Dakota State Bd. of Pharmacy v. Snyder's Drug Stores, 42 U.S.L.W. 4035 (U.S. Dec. 4, 1973); Lincoln Federal Labor Union v. Northwestern Iron \& Metal Co., 335 U.S. 525, 534-37 (1949); cf. Wellington, Common Law Rules and Constitutional Double Standards: Some Notes on Adjudication, 83 YALE L.J. 221, 272-311 (1973). 
for what the state deems necessary for the protection of public health and safety. ${ }^{49}$ Dental board regulations could probably also withstand a charge that they were not based on "substantial evidence." 0

A second due process argument might attack the procedures used by the dental board in promulgating regulations for paraprofessionals. Adjudication would not be on the merits of the regulations, but rather on issues such as the openness or fairness of the hearings or meetings at which the regulations were established, whether the board acted within its statutory authority, ${ }^{51}$ and whether the board's decision was based on relevant evidence as opposed to "mere guesswork" or "special knowledge" possessed by board members. ${ }^{52}$ While a court would not on this theory declare prohibitions on expanded functions to be substantively illegal, it could force the dental board to reconsider its regulations in an open hearing at which interested parties could produce current evidence on the ability of properly trained auxiliaries to perform expanded functions. While this argument has much merit, it has thus far been successful only in suits attacking administrative board adjudication $^{53}$ and its relevance to administrative rulemaking, the most

49. This is especially true since the decline of economic or "substantive" due process, see note 48 supra. See, as illustrative of many cases, Ferguson v. Skrupa, 372 U.S. 726 (1963); Williamson v. Lee Optical Co., 348 U.S. 483 (1955); United States v. Carolene Products Co., $30 \pm$ U.S. 144 (1938).

The rational relation test would be used to uphold not only the prohibition by a legislature of specific auxiliary functions, but also the statutory grant of power to the dental board to make regulations. See Douglas v. Noble, 261 U.S. 165 (1923), holding that a state may delegate the power to determine standards for licensing without violating the Fourteenth Amendment, so long as a grant of arbitrary power is not made.

50. Generally, a court will not overturn an administrative board decision unless there is a complete absence of "substantial evidence" to support the decision. Bockman v. Arkansas State Medical Bd., 229 Ark. 143, 145-46, 313 S.W.2d 826, 828 (1958); Ellis v. State Dep't of Public Health \& Welfare, 365 Mo. 314, 285 S.W.2d 634 (1955); S ate Bd. of Examiners in Optometry v. Marlow, 257 S.W.2d 761 (Tex. Civ. App. 1953). "Substantial evidence" is generally judicially defined in terms of the sufficiency of relevant evidence that a reasonable mind might accept as adequate to support a conclusion. Interstate Busses Corp. v. United States, 259 F. Supp. 577, 579 (D. Mass. 1966); Ammerman v. Florida Bd. of Pharmacy, 174 So. 2d 425, 426 (Fla. App. 1965); State Farm Mutual Auto Ins. Co. v. Gonzales, 83 N.M. 296, 298, 491 P.2d 513, 515 (1971); Erie Lackawanna Ry. Co. v. Pennsylvania Public Utility Comm'n, 2 Pa. Commonwealth $396,399,278$ A.2d 188, 190 (1971).

51. Since most current dental practice acts make a very general delegation of regulatory authority to the dental boards, it is difficult to ascertain exactly what the "scope" of the board's authority is. This may suggest a failure of specificity.

52. Courts have found a denial of due process where an administrative board decision was based not on pertinent evidence, but on special knowledge held by board members. New Jersey State Bd. of Optometrists v. Nemitz, 21 N.J. Super. 18, 90 A.2d 740 (1952); Application of Palmer, 275 App. Div. 5, 8.9, 87 N.Y.S.2d 655, 659, rev'd on other grounds sub nom. Palmer v. Spaulding, 299 N.Y. 368, 87 N.E.2d 301 (1949); In re Shenandoah Suburban Bus Lines, Inc., 355 Pa. 521, 50 A.2d 301 (1947); State ex rel. Puget Sound Navigation Co. v. Department of Transp., 33 Wash. 2d 448, 206 P.2d 456 (1949). Restrictions on auxiliaries thus might be susceptible to attack on the grounds that the dental board had not considered current evidence on the ability of auxiliaries to perform expanded functions, but rather arrived at the restrictions on the basis of the board members' own practice experience or "professional judgment."

53. See cases cited note 52 supra. 
important issue in the case of paraprofessionals, has not yet been decisively settled. Adjudicative proceedings, involving suspension or revocation of the professional's license, may be considered penal in nature. The entire weight of the state's enforcement mechanism is brought to bear on the individual. In rulemaking, by comparison, the conflict between state and individual is not as sharply drawn. A more exacting standard of due process is thus required in adjudication to ensure that important individual rights are not lost simply because one side has superior resources. ${ }^{.7}$ Therefore, a challenge against dental board rulemaking procedures on these due process grounds might not succeed because the procedures satisfy the lower standards. ${ }^{.5}$

A final due process argument would focus on the "conclusive presumption" aspect of the licensing system. In several cases the Supreme Court has invalidated statutory or administrative presumptions which did not allow plaintiffs to dispute a fact necessary to an administrative decision. ${ }^{5 b}$ Under this doctrine, three elements seem necessary for a pre-

54. A comparison might be drawn between the passage of a criminal statute by a legislature and the enforcement of that statute in the trial of an accused. In the former, interested parties may present biased or slanted evidence to the legislators without limit, and the legislature is only obliged to obey a few rules of parliamentary and legislative procedure in reaching its decision. A reviewing court will generally defer to the legislative judgment, imposing only broad boundaries of due process. In the latter, the court and the parties must comply with strict standards of duc process and admissibility of evidence.

55. A recent Supreme Court decision suggests that dental boards may be vulnerable to due process attack for their composition. Gibson v. Berryhill, 411 U.S. 564 (1973). That case, however, like the cases cited note 52 supra, involved adjudicative, quasijudicial proceedings by the state licensing board against optometrists who allegedly engaged in unprofessional conduct by working for a "corporate optometrist," rather than in individual practices. The Supreme Court affirmed the district court's determination that a fair and impartial hearing in conformity with the Fourteenth Amendment could not be held because members of the licensing board could only be selected from members of the Alabama Optometric Association, which only admitted self-employed optometrists to its organization. The Court stated that, "Those with substantial pecuniary interest in legal proceedings should not adjudicate those disputes." Id. at 579 , citing Tumey v. Ohio, 273 U.S. 510 (1927). The district court had found evidence of this pecuniary interest in the potential gain in business to board members and others in the Alabama Optometric Association if plaintiffs' licenses were revoked and their employer were thus no longer able to continue in business. Berryhill v. Gibson, 331 F. Supp. 122, 125-26 (M.D. Ala. 1971).

56. Cleveland Bd. of Educ. v. LaFleur, 42 U.S.L.W. 4186 (U.S. Jan. 21, 1974) (conclusive presumption that every teacher four to five months pregnant is physically incapable of performing her duties used to justify mandatory leave of absence); Vlandis v. Kline, 412 U.S. 441 (1973) (conclusive presumption that students were not bona-fide in-state residents, for purposes of tuition assessment, if they had legal address outside state at some specified prior date); Stanley v. Illinois, 405 U.S. 645 (1972) (conclusive presumption that all unmarried fathers are unsuitable and neglectful parents used to justify denial of custody of child); Bell v. Burson, 402 U.S. 535 (1971) (refusal to consider whether driver involved in accident was at fault before requiring posting of financial responsibility bond to avoid license suspension); Carrington v. Rash, 380 U.S. 89 (1965) (conclusive presumption that no serviceman stationed in Texas intended to remain there permanently used to justify conclusion that servicemen were not bonafide residents and hence could not vote in Texas); Heiner v. Donnan, 285 U.S. 312 (1932) (conclusive presumption that gifts made within two years prior to donor's death were made in contemplation of death, thus requiring payment of higher tax). 
sumption to violate the due process clause of the Fourteenth Amendment: (1) the presumed fact is not always true; (2) the interest at stake outweighs the administrative inconvenience to the state of making individual determinations; ${ }^{57}$ (3) the purpose of the state's statutory scheme can in fact be better effectuated through individual determination than through the use of the presumption. ${ }^{58}$ The conclusive presumption that dental auxiliaries are incapable of performing certain tasks is certainly not true; the auxiliaries themselves have a substantial interest in pursuing their occupations; ${ }^{59}$ and the state's goal of assuring high-quality dental care would be better effectuated by an examination process that would certify qualified auxiliaries to practice expanded functions. ${ }^{60}$

To establish an antitrust violation against a dental licensing board, auxiliaries would have to show a "conspiracy in restraint of trade."61

57. Stanley v. Illinois, 405 U.S. 645, 658 (1972). This may be satisfied if the state has a "reasonable alternative means of "making the crucial determination." Vlandis v. Kline, 412 U.S. 441,452 (1973).

58. In Vlandis v. Kline, 412 U.S. 441 (1973), for example, plaintiff presented evidence of being a bona-fide resident, even though she had just moved to the state; she had a substantial pecuniary interest due to the lower university tuition rates accorded in-state students; and the state's goal-greater stubsidization of educational costs for residents than for nonresidents-could be better effectuated by an alternative process which would allow students to establish the fact of their residency on a caseby-case basis. In Cleveland Bd. of Educ. v. LaFleur, 42 U.S.L.W. 4186 (U.S. Jan. 21, 1974), pregnant teachers were often capable of performing their duties beyond the "fifth month" cutoff date; plaintiff teachers had a substantial interest in retaining their jobs and maintaining privacy in their marital affairs; and the city's goalmaintaining continuity of instruction-would have been better achieved through in. dividual determination, since teachers were frequently forced to go on leave even though their "cut-off-date" came shortly before the end of a school term. See also cases cited note 56 supra.

59. Cf. Cleveland Bd. of Educ. v. LaFleur, 42 U.S.L.W. at 4195 (Rehnquist, J., dissenting).

60 . The "examination" refers to a proposed alternative method of licensing auxiliaries which is discussed at pp. 824-25 infra.

61. This discussion is loosely based on the requirements of the Sherman Antitrust Act, 26 Stat. 209 (1890), as amended 15 U.S.C. $\$ \S 1-7$ (1970). However, resort to state statutes would be necessary if plaintiffs could not show sufficient effect on interstate commerce to involve the Sherman Act. (For a discussion of the jurisdictional problems in bringing the "learned professions" under the coverage of the Sherman Act, see Note, The Applicability of the Sherman Act to Legal Practice and Other "Non-Commercial" Activities, 82 YALE L.J. 313 (1972). The author, stating that "Congress intended the Act to reach anti-competitive behavior no matter where it arises," argues that the professions, the educational sector, amateur athletics, etc., are within the jurisdiction of the Sherman Act. Id. at 327, 336-37.) In terms of substantive law, statutes similar to the Sherman Act are in force in many states. See, e.g., ALA. CodE tit. 14, $\$ 54$ (1958); Cal. Bus. \& Prof. Code $\$ 16720$ (West 1964); Hawail Rev. Stat. \$ 480-4(a) (1968); IDAho Code ANN. \$ 48-101 (1948); Ill. ANN. Stat. ch. 38, \$ 60-3 (Smith-Hurd 1970); IND. ANN. STAT. $\$ 23-116$ (1964); LA. REv. STAT. \$ 51:122 (1965); ME. Rev. STat. tit. 10, § 1101 (Supp. 1973); Minn. Stat. Ann. \$§ 325.8013, 325.8014 (Supp. 1973); Mo. ANN. STAT. $\$ \$ 416.010,416.020$ (1949); NEB. Rev. STAT. \$ 59-801 (1943); N.Y. GeN. Bus. Law $\$ 340$ (McKinney 1968); N.C. GEN. STAT. \$ 75-I (1965); WASH. Rev. Code ANN. \$ 19.86.030 (Supp. 1972); Wis. STAT. ANN. \$ 133.01 (Supp. 1973). Courts will often give these statutes the same interpretation and construction as the Sherman Act (see, e.g., Minnesota v. Northern Securities Co., 123 F. 692 (D. Minn. 1903), rev'd on other grounds, 194 U.S. 48 (1904); Chicago Title Ins. Co. v. Great 
Arguably, both elements could be established. The conspiracy might be inferred from the fact that all board members were members of a state dental association supporting American Dental Association policy regarding EFA's. ${ }^{62}$ The restraint of trade might be established by a showing of the effect of the restrictive regulations on prices and quantity in the dental care market; ${ }^{63}$ or by showing the damage to the individual competitors (the paraprofessionals) who are excluded from performing expanded functions by those already performing those functions (dentists). ${ }^{64}$

However, the doctrine that the antitrust laws do not apply to valid state action limits the likelihood of successful suits against state dental boards. ${ }^{65}$ Auxiliaries challenging state regulations might still avoid this

Western Financial Corp., 69 Cal. 2d 305, 315, 444 P.2d 481, 487, 70 Cal. Rptr. 849, 855 (1968); Carl N. Swenson Co. v. E.C. Braun Co., 272 C.A. 2d 366, 368, 77 Cal. Rptr. 378, 379 (1969)); or give a judgment under one res judicata effect in a snit on the other (see, e.g., Fowler Mfg. Co. v. Gorlick, 415 F.2d 1248, 1254 (9th Cir. 1969), cert. denied, 396 U.S. 1012 (1970); Englehardt v. Bell \& Howell Co., 327 F.2d 30 (8th Cir. 1964)); or consider Sherman Act cases in deciding suits under state statutcs or common law (see, e.g., Grillo v. Board of Realtors, 91 N.J. Super. 202, 219, 219 A.2d 635, 645 (1966); Rose v. Vulcan Materials Co., 282 N.C. 643, 655, 194 S.E.2d 521, 530 (1973)).

62. See, e.g., Interstate Circuit, Inc. v. United States, 304 U.S. 55 (1938); note 41 supra.

63. The test of illegality has been satisfied where the conspiracy or agreement has the necessary consequence that prices will be controlled, production limited, or competition suppressed. See, e.g., United States v. Container Corp. of America, 393 U.S. 333 (1969); United States v. Socony-Vacuum Oil Co., 310 U.S. 150 (1940) (Sherman Act cases); Jackson v. Sullivan, 276 Ky. 666, 124 S.W.2d 1019 (1939); Pocahontas Coke Co. v. Powhatan Coal \& Coke Co., 60 W. Va. 508, 56 S.E. 264 (1906).

64. There have been several cases in which antitrust violations were based on injury to individual competitors. See, e.g., Klor's, Inc. v. Broadway-Hale Stores, 359 U.S. 207 (1959).

This rationale has apparently been used in several antitrust cases in medicine, c.g., Willis v. Santa Ana Community Hospital Ass'n, 58 Cal. 2d 806, 376 P.2d 568, 26 Cal. Rptr. 640 (1962); Group Health Cooperative v. King County Medical Society, 39 Wash. $2 \mathrm{~d} 586,237$ P.2d 737 (1951). Especially instructive is American Medical Ass'n v. United States, 130 F.2d 233 (D.C. C.ir. 1942), aff'd, 317 U.S 519 (1943), in which the court said: The fact that changes in social and economic conditions may result even in depriving professional people of opportunities formerly open to them does not justify or excuse their use of criminal methods to prevent change or to destroy new institutions.

130 F.2d at 245 .

Professions exist because the people believe they will be better served by licensing especially prepared experts to minister to their needs. The licensed monopolies which professions enjoy constitute, in themselves, severe restraints upon competition. But they are restraints which depend upon capacity and training, not special privilege. Neither do they justify concerted criminal action to prevent the people from developing new methods of serving their needs.

Id. at 246.

Group Health and American Medical Ass'n also established that, at common law, the term "restraint of trade" was deemed applicable to the practice of medicine. 39 Wash. 2d at 638,237 P.2d at 765; 130 F.2d at 235 .

65. See Eastern Railroad Presidents Conf. v. Noerr Motor Freight, Inc., 365 U.S. 127, 136 (1961) (dictum); Parker v. Brown, 317 U.S. 341 (1943); United States v. Rock Royal Co-op, 307 U.S. 533 (1939). Even in American Medical Ass'n v. United States, 130 F.2d 233 (D.C. Cir. 1942), aff'd, 317 U.S. 519 (1943), there was substantial dictum to the effect that defendant might not be in violation of the Sherman Act had it been acting under a legislative delegation of the power and duty to regulate professional education, licensure, or discipline. 130 F.2d at 247. 
bar by demonstrating that the dental board was acting outside the scope of its authority, and hence was not engaging in "valid state action" in promulgating the challenged regulations. ${ }^{66}$ This would be a difficult demonstration, however, due to the Supreme Court's policy of deferring to state programs in the health and safety $\operatorname{area}^{67}$ (a policy that has been specifically applied where a state regulatory statute conflicted with the Sherman Act). ${ }^{68}$ Further, the very general delegation of regulatory authority by state statutes to dental boards would make it difficult to ascertain exactly what is the "scope of authority."

Despite the dim prospects for success of most of these due process and antitrust arguments, there are indications that the judiciary may scrutinize licensing board actions more closely in the future. ${ }^{60}$ As outside support for judicial intervention grows, ${ }^{70}$ courts may become willing to find the actions of the professional groups charged with carrying out the licensing schemes to be outside the scope of "valid state action" and

66. In Silver v. New York Stock Exchange, 373 U.S. 341 (1963), defendant stock exchange had been granted the power to formulate rules governing the conduct of its members by the Securities Exchange Act of 1934, 15 U.S.C. $\$ 78 \mathrm{f}$ (1970). Pursuant to its rules, defendant discontinued the direct wire connections between plaintiffs, two over-the-counter securities dealers, and several members of the Exchange, without granting plaintiffs a hearing or informing them of the reasons for this action. The Supreme Court held that defendant's action was outside the scope of its statutory authority to engage in self-regulation; hence removal of the connections was a group boycott of plaintiffs illegal under $\$$ I of the Sherman Act. 373 U.S. at 364-65. The Court said that "exchange self-regulation is to be regarded as justified in response to antitrust charges only to the extent necessary to protect the achievement of the aims of the Securities Exchange Act." Id. at 361. See also Hecht v. Pro-Football, Inc., 444 F.2d 931 (D.C. Cir. 1971), cert. denied, 404 U.S. 1047 (1972) (agency empowered by statute to operate municipal stadium exceeded its authority by granting one football team the exclusive right to use the stadium for professional football; held, the statute gave the agency no immunity from antitrust liability for this conduct).

67. See cases cited note 48 supra.

68. [State regulations] are to be upheld because upon a consideration of all the relevant facts and circumstances it appears that the matter is one which may appropriately be regulated in the interest of the safety, health and well-being of local communities, and which, because of its local character, and the practical difficulties involved, may never be adequately dealt with by Congress.

Parker v. Brown, 317 U.S. 341, 362-63 (1943). In Hitchcock v. Collenberg, 140 F. Supp. 894 (D. Md. 1956), aff'd mem., 353 U.S. 919 (1957), it was held that the State Board of Medical Examiners was exempt from the Sherman and Clayton Acts while carrying out its statutory duty of granting licenses.

69. See, e.g., Gibson v. Berryhill, 411 U.S. 564 (1973); note 55 supra.

70. The federal Special Task Force on Higher Education recently urged the government to adopt a more vigilant antitrust posture toward professional and occupational groups that exert control over who works in their field of activity. The Task Force called for clarification of law and regulatory responsibility among arms of government concerned with the professional groups and for an investigation of "requirements unrelated to the proficiencies needed to protect consumers and successfully practice one's profession." Frank Newman, the Task Force's director, foresaw government lawsuits against occupational organizations-although they would probably not arise until the distant future. N.Y. Times, Oct. 28, 1973, \& 1, at 16, col. 1 . For the Task Force's report, see National Policy on Higher Education, Report of the Special Task force to the Secretary of Health, Education and Welfare, Oct. 1973. A recent law review Note argues that courts should use due process to assert a power of review over occupational licensing systems. Note, supra note 46, at 1129. 
hence violative of the antitrust laws. Courts may also become willing to find present auxiliary licensing systems to be violative of Fourteenth Amendment due process on one or more grounds.

Although judicial attack may hold some possibilities for reform, significantly more effective dental auxiliary licensing systems could be achieved with a few statutory changes. One desirable modification would be elimination of all statutory serial listing of prohibited or permitted dental auxiliary functions. Such a change would make the statutes more flexible, would prevent them from being absolute bars to the performance of certain tasks, and along with stricter statutory guidelines for dental board actions would encourage faster response to new methods and techniques in dental practice.

Elimination of such serial listing would mean giving regulatory boards a much broader rulemaking power to determine what auxiliaries may legally do. The changed statutes should therefore set explicit guidelines to govern the boards' decisionmaking. Strict guidelines would also give courts a clearer basis for determining when a licensing board has exceeded the scope of its authority. The guidelines should cover these points: (1) the board would be directed to allow individual auxiliaries to perform functions commensurate with their demonstrated training and competence; (2) in establishing certification standards, the board must consider the need to maintain the quality of care received by the public; (3) but this must be weighed against the need for efficiently-provided, low-cost dental care for the public. ${ }^{71}$

The new system should allow auxiliaries to perform functions commensurate with their training. The traditional statutory categorization of auxiliaries into just two groups, assistants and hygienists, should be eliminated. Instead, either a greater number of "levels" or "classes" of auxiliary should be established, or the statute should simply direct the board to license any auxiliary to perform any function which that auxiliary demonstrates he can perform with sufficient skill and competence.

71. One state, Vermont, has already adopted a statute utilizing guidelines such as these. It reads in pertinent part as follows:

A hygienist may perform such duties for which he has been qualified by successful completion of the normal curriculum offered by schools of dental hygiene accredited by the American Dental Association or in continuing education courses approved by the board of dental examiners.

VT. STAT. ANN. \$ 26-854 (1973).

The secretary shall direct the board to prepare and promulgate regulations prescribing minimum educational requirements, training experience, and professional standards necessary for practice pursuant to this chapter as a dental assistant. In preparation of such regulations the board shall consider the need to improve the efficiency and reduce the cost of dental service in the state consistent with maintenance of the highest possible standards of dental care.

Id. $\$ 26-862$. 
The certification of the EFA's skill and competence to perform a certain task could be accomplished in either of two ways. First, the statute might specify that auxiliaries be allowed to perform any functions learned in courses taken at approved dental auxiliary schools. Additionally (or alternatively), the statute could direct the board to license an auxiliary to perform any function which he demonstrates the capability to perform in an examination given by the board.

Several states have already made limited attempts to enact these recommended changes. The Minnesota statute, for example, states, "The board may permit differing levels of dental assistance based upon recognized educational standards, approved by the board, for the training of dental assistants."'72 Pursuant to this provision, the Minnesota dental board issued regulations defining three types of dental assistants, two of which are permitted some expanded functions, in addition to the dental hygienist. ${ }^{73}$

In order to eliminate possible conservative bias resulting from statutory requirements for board membership, and to prevent control of the boards by those who may benefit from limitation of the functions auxiliaries may perform, the statutes should be amended to liberalize the composition of these boards. The statutes should require the presence of at least one dental school faculty member, ${ }^{74}$ one recent dental school graduate, and one auxiliary on the board. ${ }^{75}$ They should also require that nominations for membership come from groups outside the state dental society, such as dental educators, public service groups, and the profession at large. These changes would increase the likelihood that the board, in deciding whether to allow any expanded function, would receive some input from persons with exposure to or familiarity with

72. Minn. Stat. ANN. \$ 150A.10(2) (1969).

73. D. Johnson \& F. Holz, supra note 33, at 68-72. The New Hampshire statute makes the following authorization: "The board shall have the power to make, amend, and adopt rules and regtilations governing the conduct of dental hygienists and other auxiliary personnel employed by licensed dentists." N.H. REv. STAT. ANN. \$ 317-A:12 (Supp. 1972). Pursuant to this provision, the dental board has issued regulations defining (by educational status) four levels of dental assistant. As the assistant progresses through the levels, he may perform increasingly complicated functions. Additionally, the regulations state that auxiliaries may perform further duties when the board feels their educational attainment justifies such further duties. D. Johnson and F. Holz, supra at 88-90.

Other states whose dental boards have defined several levels of dental assisting, based on education, include Florida, North Carolina, and Oregon. Id. at 28-32, 97-99, 111-16. Others, such as Oklahoma, while not specifically defining several levels of auxiliary, have made rulings to the effect that auxiliaries who complete further training, approved by the dental board, may perform further functions. Id. at 109 .

74. Since several states do not have dental schools within their borders, these states would have to recruit their dental school faculty member from a dental school in another state.

75. The auxiliary member could be excluded from participation on matters relating to the examining, licensing, and disciplining of dentists. 
the new technique. The changes may also release the dental board from the sole control of those who have the greatest interest in restricting the supply of dental services.

Finally, technical "advisory boards" should be created to assist the licensing agencies. These advisory boards, which should be more heavily composed of dental educators and leading auxiliaries than the licensing boards, would study changes in auxiliary methods and techniques, keep the licensing boards informed in this area, and make recommendations on new functions which auxiliaries could be allowed to perform and on different types of certification examinations. As an additional duty the advisory boards might be made the accrediting bodies for auxiliary schools. ${ }^{\text {}}{ }^{6}$

\section{Conclusion}

The paraprofessional can be valuable in increasing the supply of dental care and thereby decreasing its price. State licensing systems should permit flexible use of paraprofessionals in the provision of dental services, consistent with the protection of public safety, rather than create a bar to their utilization. Paraprofessionals should be allowed to perform expanded functions commensurate with their training and competence; dentists should not be allowed to use their control of licensing boards to inhibit the utilization of the paraprofessional.

Many of the restrictions placed on dental auxiliaries by contemporary licensing systems are unjustifiable in view of empirical evidence and the recognized purposes of licensing. Greater judicial activism is needed to eliminate abuses, and statutory changes are needed to eliminate the causes of abuses.

76. In addition to these changes in the dental practice acts themselves, a whole range of complementary policies can be suggested to make effective use of dental auxiliaries. These include subsidies to dentists to hire or train dental auxiliaries; subsidies or low-cost loans to enable dentists to purchase additional equipment for the use of newly-hired dental auxiliaries; subsidies to dental auxiliary schools; and subsidies for dental school courses and continuing education courses to instruct dental students and dentists in the efficient utilization of expanded function auxiliaries. Statutory restrictions on advertising by dentists (see, e.g., IND. ANN. STir. $\$$ 63-518(11) (1973); Iowa Code AN. \$ 153.32 (1972); MICH. CoMp. LAws ANN. \$ 338.217 (1967); N.J. STAT. ANN. \& 45:6-7 (1963); VA. CODE ANN. \$ 54-187(7) (1973); W.isit. Rev. Cone ANN. $\$ 18.32 .290$ (1961)) could be relaxed so that dentists who hire expanded function auxiliaries, and who thus may have "excess capacity," can advertise that fact and attract unserviced customers.

On a larger scale, programs such as those used in New Zealand could be developed in underserviced areas. (See Walsh, supra note 17.) A small number of dentists, working with large groups of expanded function auxiliaries, could provide necessary care in urban ghettos, in rural districts, and in schools. The programs could be supervised by the United States Public Health Service or by state, county, or municipal boards of health. 